\title{
Perspectivas para o empoderamento da mulher através da releitura de clássicos infantis para séries iniciais do ensino fundamental
}

\author{
Perspectives for women's empowerment through the reading of children's \\ classics for initial educational series
}

\author{
Sandriane Proença Figueredo ', Jefferson Marçal da Rocha "
}

\section{RESUMO}

Este artigo aborda o tema empoderamento feminino e visa refletir sobre uma proposta pedagógica para os alunos do ensino fundamental de uma Escola Pública, do município de São Gabriel/RS. Alunos e alunas do quinto ano do ensino fundamental. O objetivo foi relatar uma reflexão sobre o papel da mulher na sociedade contemporânea, a partir da releitura de clássicos infantis. Considera-se que ao se discutir novas práticas de ensino e aprendizagem, relacionados ao papel da mulher no mundo contemporâneo, podemos estimular os educadores a buscarem novas perspectivas para suas práticas em todas as áreas do conhecimento. $O$ resultado destas práticas após análises dos relatos dos alunos foi à conscientização de todos e todas sobre a importância da luta e conquistas femininas na sociedade contemporânea. Considerou-se que "princesas contemporâneas" podem salvar-se e alcançar o esperado "final feliz", que a maioria dos contos de fadas traz, sem, contudo, contar com um "príncipe encantado". Neste contexto percebeu-se que as conquistas das mulheres fazem parte de uma realidade contemporânea, que deve ser sempre relacionada a todas as práticas de ensino.

Palavras-chave: Educação; Empoderamento; Ensino; Superação.

\section{ABSTRACT}

This article discusses the issue of women's empowerment and aims to reflect on a pedagogical proposal for primary school students in a public school in the municipality of São Gabriel/RS. Students from the fifth year of elementary school. The objective was to report a reflection on the role of women in contemporary society, starting from a rereading of children's classics. It is considered that by discussing new teaching and learning practices related to the role of women in the contemporary world, we can stimulate educators to seek new perspectives for their practices in all areas of knowledge. The result of these practices after analyzing the students' reports was to raise everyone's awareness about the importance of women's struggle and achievements in contemporary society. It was considered that "contemporary princesses" can save themselves and achieve the expected "happy ending" that most fairy tales bring, without, however, counting on a "prince

\footnotetext{
I Graduada em Pedagogia. Centro Universitário - UNINTER. E-mail: sandriane.figueiredo91@gmail.com. ORCID: https://orcid.org/0000-0002-7988-355X.

" Professor do Programa de Pós Graduação em Educação. Unipampa. E-mail: jeffersonmrocha@gmail.com. ORCID: http://orcid.org/0000-0002-5873-0992.
} 
charming". In this context it was realized that women's achievements are part of a modern reality, which must always be related to all teaching practices.

Keywords: Education; Empowerment; Teaching; Overcoming.

\section{INTRODUÇÃO}

A ideia deste artigo surgiu ao constatar, na prática de professora das séries iniciais (da primeira autora) de uma escola pública, a necessidade de se refletir sobre o contexto social abordado nos clássicos infantis.

Observando que o contexto atual requer uma mudança de postura de homens e mulheres frente a temas como: direitos da mulher, machismo, igualdade de gênero, misoginia entre outros, foi proposto aos alunos uma reflexão referente à luta das mulheres por conquistas de direitos e autonomia; partindo de leituras de clássicos infantis que, em sua maioria, retratam as princesas à espera de seus príncipes encantados e da constatação de que é possível criar no ambiente escolar novas perspectivas de compreender o papel das mulheres na sociedade (BOTTON, 2018).

Considerando, em especial, que a independência da mulher garante que seus objetivos sejam alcançados sem a necessidade da espera de alguém do gênero masculino para se sentirem completas e felizes.

Assim o objetivo deste trabalho foi comparar o papel da mulher na sociedade contemporânea em relação a épocas passadas e refletir, através de práticas pedagógicas de ensino, as suas lutas e conquistas. A partir disto identificar, através das histórias clássicas da literatura infantil, fatores que não condizem mais com a sociedade contemporânea. Outro objetivo, não menos relevante, foi desenvolver o pensamento crítico dos alunos e alunas em relação a fatores relacionados ao empoderamento feminino na contemporaneidade, com isto temas como machismo, misoginia, feminicídio, entre outros, foram sendo incorporados as discussões e reflexões dos educandos e educandas. 


\section{REFERENCIAL TEÓRICO}

O referencial teórico deste artigo foi estruturado com a finalidade de dar subsídios para as discussões e análises que serão realizadas das atividades desenvolvidas com a turma, está dividido em três tópicos: caracterização da escola, clássicos infantis e o empoderamento feminino.

\subsection{Caracterização da Escola - Objeto de estudo}

A Escola pesquisada foi fundada pela administração municipal do município de São Gabriel no ano de 1937 com a intenção de suprir a necessidade da comunidade gabrielense de uma escola que recebesse os alunos de uma região da cidade em que ainda não havia estabelecimento de ensino. Os moradores desta região pertenciam a uma classe social de trabalhadores rurais e urbanos que não tinham acesso as escolas públicas, localizadas em regiões mais centrais da cidade.

Nos primeiros anos, foram ofertadas apenas as séries iniciais do atual ensino básico. Vinte anos depois, em fevereiro de 1958, essa passou a ser uma escola administrada pelo Estado do Rio Grande do Sul e passou a oferecer o ensino fundamental completo (ROCHA; HAMMES, 2018).

Em 2019, a escola oferece os Ensinos Fundamental e Médio, nos três turnos, e atende anualmente uma média de 600 alunos. O corpo docente é composto hoje por 60 professores e possui 12 funcionários que trabalham na secretaria, biblioteca, cozinha, limpeza e segurança. As famílias dos alunos possuem renda familiar em torno de dois salários mínimos. Diversos estudantes da escola entram no mercado de trabalho, geralmente em serviços mal remunerados e com poucas perspectivas de evoluírem profissionalmente, antes de concluírem a Educação Básica. Estes dados são detalhados nos documentos analisados para esta pesquisa (PDI, Regimento, etc.).

Pelos dados do Índice de Desenvolvimento da Educação Básica (IDEB), a escola pesquisada apresentou sensível melhoria no que diz respeito aos anos iniciais do Ensino 
Fundamental, passando de 4,4 para 4,6 na avaliação divulgada no Censo Escolar de 2014. Vale mencionar que, embora o desempenho da Escola tenha melhorado, ficou ainda abaixo da média nacional $(4,9)$, da estadual $(5,4)$ e do próprio município de São Gabriel $(4,8)$.

Já nas séries finais do Ensino Fundamental, a escola apresentava média de 3,0 no ano de 2011 e passou a 2,6, na última avaliação em 2013, ficando muito além da média nacional $(4,0)$, estadual $(4,0)$ e do município $(2,9)$.

Outros dados a se salientar referem-se às Taxas de Rendimento (aprovação e reprovação) e ao Movimento escolar (abandono) dos alunos do Ensino Fundamental e Médio. Nesse aspecto, a escola apresenta índices oscilantes para o Ensino Fundamental quando se verifica que, em 2014, a taxa de aprovação foi de 74,2\%; em 2015, de 70,7\% e, em 2016, de 76,5\%. As taxas de reprovação nesse mesmo período foram, respectivamente, $15 \%, 23,1 \%$ e $10,9 \%$.

Um fato preocupante para os educadores e direção da escola é a taxa de abandono, que aumentou para mais de $100 \%$ no período analisado, passando de $6,2 \%$ em 2014 para 12,6\%, em 2016. Especialmente em relação ao Ensino Médio, as taxas divulgadas pelo Censo Escolar em 2014 preocupam, pois a aprovação registrada passa de $67,8 \%$, em 2012 , para $63,1 \%$, em 2013 , e para $58,8 \%$ em 2014 . A reprovação registrada foi de 12,1\%, em 2012; 16,9\%, em 2013 e em 18,9\%, em 2014. Já o movimento dos alunos no que se refere ao abandono é 20,1\% em 2012 e diminui para 20\% em 2013, mas volta a crescer em 2014, quando se registram 22,3\% dos alunos matriculados no referido ano.

Em relação à Prova Brasil, verificou-se que nos anos iniciais do Ensino Fundamental ( $1^{\circ}$ ao $5^{\circ}$ ano), a escola ficou acima da média nacional, tanto em Língua Portuguesa quanto em Matemática. Em Língua Portuguesa, a média nacional foi 189,71 e a da escola foi 190,39, no ano de 2013; uma melhora em relação ao ano de 2011, em que a média nacional era de 185,69 e a da escola de 173,49. Em Matemática, em 2013, a média nacional foi 205,08 e a da escola 205,83, demonstrando também uma sensível 
melhora em relação ao ano de 2011, quando a média nacional foi 204,58 e a escola apresentou média 190,16 (ROCHA; HAMMES,2018).

\subsection{Clássicos infantis e sua influência na perpetuação do machismo}

Para que uma história realmente prenda a atenção da criança, deve entretê-la e despertar a sua curiosidade. Contudo, para enriquecer a sua vida, deve estimular-Ihe a imaginação, ajudá-la a desenvolver seu intelecto e ajudar a tornar clara as suas emoções. Uma história deve ter harmonia com ansiedades e aspirações de cada idade da criança, reconhecer plenamente suas dificuldades de compreensão e amadurecimento, mas, ao mesmo tempo, sugerir soluções para os problemas que elas vivem. Neste sentido contar uma história para alunos e alunas do ensino fundamental em uma escola pública de um bairro de periferia de uma cidade do interior do Rio Grande do Sul, é um desafio para educadores e educadoras, que percebem que o processo de ensino e aprendizagem deve estar atrelado a uma construção social e cultural de cada realidade.

No entender de Freire (2008, p. 11), "A leitura do mundo precede a leitura da palavra, daí que a posterior leitura desta não possa prescindir da continuidade da leitura daquele". Nesse sentido, pode-se afirmar que a leitura é um processo continuado que se inicia no berço e só termina no momento da morte, sendo que aprender a leitura do mundo possibilita ensinar, aprender fornecer dados e revelar o oculto.

Os clássicos infantis, em sua maioria, mostram por traz de suas histórias de contos de fadas, príncipes e princesas, a influência na perpetuação do machismo, pois liga a questão que as princesas desses contos só conseguem o final feliz quando se casam com o príncipe. É o que acontece nos contos Branca de neve (1817), Rapunzel (1815) e Bela Adormecida (1812), três dos contos mais difundidos na história da humanidade.

Assim não se pode negar, por esta análise, o fato de que os contos de fadas foram criados em uma sociedade diferente da que vivemos hoje, onde as mulheres não tinham direitos e eram totalmente submissas aos homens, mas é necessário nos processos educativos, especialmente entre crianças, tornar uma perspectiva de contextualizar a 
mudança da sociedade no decorrer do tempo e que na contemporaneidade. Onde toda mulher deve encontrar-se plena, completar-se e sentir-se feliz sozinha, se assim desejar.

\subsection{0 empoderamento infantil feminino}

Segundo Coelho (2014) a decisão de focar nas crianças - especialmente nas meninas - parte da necessidade de criar coletivamente estratégias e alternativas para empoderar, ou seja, libertar as meninas da opressão de gênero que sofrem por terem nascido meninas.

Atualmente, no Brasil, há diferentes ações que promovem o empoderamento de meninas e mulheres, bem como outras para ambos os sexos que trabalham com promoção de igualdade de gênero e sensibilização contra a desigualdade. Nos últimos anos, notou-se crescimento no número de projetos voltados para o público infantojuvenil, mas o trabalho com as crianças de menor idade ainda precisa de mais investimentos, pois conta com poucas iniciativas (SANTOS; MORA; DEBIQUE, 2016).

Segundo a cartilha dos Princípios de Empoderamento das Mulheres (ONU MULHERES; PACTO GLOBAL DAS NAÇÕES UNIDAS, 2016), uma das alternativas para mudar o cenário de submissão ao homem é trabalhar o empoderamento feminino, sendo esse um dos primeiros passos na busca por uma sociedade com igualdade de gênero. Empoderamento é um conceito que não deve ser entendido pela simplicidade de "dar poder às mulheres", mas como estratégias em nível individual e coletivo que promovam mudanças na situação de submissão feminina construída historicamente (LEÓN, 2000).

\section{METODOLOGIA}

Esta pesquisa se constitui em uma análise bibliográfica e uma pesquisa ação educativa. Nesse sentido, será utilizado como método de pesquisa o procedimento de pesquisa-ação, que segundo Thiollent (2011) vem ganhando importância em diversos âmbitos de pesquisa nas ciências humanas, em especial na Educação, exercendo um 
papel significante na aprendizagem e nos estudos em que os pesquisadores estão envolvidos por sua própria prática. Segundo esse autor, a pesquisa-ação é definida como:

[...] um tipo de pesquisa social com base empírica que é concebida e realizada em estreita associação com uma ação ou com uma resolução de um problema coletivo no qual os pesquisadores e os participantes representativos da situação ou do problema estão envolvidos de modo cooperativo ou participativo (THIOLLENT, 2011, p.20).

Justifica-se, portanto, nesta pesquisa a definição do procedimento da metodologia pesquisa-ação, pela possibilidade de se investigar como se dá a incorporação dos saberes, fazeres e posturas em educandos e educandas das séries iniciais de uma escola pública do estado do RS.

A pesquisa-ação para Thiollent (2011) tem dois objetivos: o prático, que visa contribuir com uma avaliação do problema central da pesquisa, e, o da construção de um novo conhecimento, no qual o educando obterá informações aumentando assim, o conhecimento de determinadas situações e ou temas, possibilitando a compreensão mais complexa do mundo a sua volta.

Em relação ao ciclo básico de reflexão-ação, a metodologia que está inserida nos inúmeros tipos investigação-ação, deve-se aprimorar a prática entre a ação e a investigação ao seu respeito, com planejamento e avaliação buscando um maior aprendizado ao longo do processo em relação à prática e a própria investigação (TRIPP, 2005).

Partindo dessa definição de escolha da metodologia do processo de pesquisa e do pressuposto de não querer ser uma mera pesquisadora, e sim, contribuir de maneira significativa com o processo de ressignificação do papel da mulher no contexto atual entre minhas alunas e alunos, articulando-o aos saberes da educação básica e possibilitando a participação dos alunos na construção de uma nova postura no mundo. Concretiza-se a pesquisa-ação como estratégia metodológica em caráter de pesquisa social pretendendo sempre observar os aspectos apresentados por Thiollent (2005): 
a) há uma ampla e explícita interação entre pesquisadores e pessoas implicadas na situação investigada;

b) desta interação resulta a ordem de prioridade dos problemas a serem pesquisados e das soluções a serem encaminhadas sob forma de ação concreta;

c) o objeto de investigação não é constituído pelas pessoas e sim pela situação social e pelos problemas de diferentes naturezas encontrados nesta situação;

d) o objetivo da pesquisa-ação consiste em resolver ou, pelo menos, em esclarecer os problemas da situação observada;

e) há, durante o processo, um acompanhamento das decisões, das ações e de toda a atividade intencional dos atores da situação;

f) a pesquisa não se limita a uma forma de ação (risco de ativismo): pretende-se aumentar o conhecimento dos pesquisadores e o conhecimento ou o "nível de consciência" das pessoas e grupos considerados.

\subsection{Procedimentos metodológicos - instrumentos}

Os instrumentos para desenvolver a pesquisa foram: pesquisa bibliográfica sobre o tema dos clássicos, comparando-os; escrita de um novo desfecho para o final dos mesmos, onde em todos havia o "príncipe encantado" ligado ao "final feliz"; assistir e analisar filmes relacionados a sociedade contemporânea onde as princesas lutavam por seus sonhos sozinhas e o amor verdadeiro estava relacionado a um amor maternal; conversas e debates sobre os direitos das mulheres; produção de texto relatando a história de uma princesa que se salvou sozinha; confecção de princesas relacionando a matemática, com uso de formas geométricas; escrita de um livro com a história criada da produção de texto, com capa e a bibliografia do autor e com a foto de cada aluno.

Assim o resultado deste artigo está baseado em uma reflexão teórica, após uma revisão bibliográfica sobre a questão da mulher nos clássicos infantis: Bela Adormecida, Rapunzel e Branca de Neve, onde no contexto, elas precisam ser salvas por um príncipe para conseguirem ser felizes para sempre. 
Houve a comparação das histórias lidas com a realidade dos dias de hoje, para que os alunos percebam que grande parte dos clássicos infantis tem a presença de um príncipe, que a salva de alguma situação no desenrolar do conto. Neste caso a reflexão partia se estas situações condiziam com o atual contexto social, em que a mulher assume papeis de protagonistas de suas próprias vidas.

Baseado na teoria de Bettelheim (2008) surgiu na prática em sala de aula a ideia da confecção dos livros pelos alunos. A sugestão de que a história fosse baseada em algum acontecimento pessoal e real foi proposital, para que eles pudessem relatar esta história e sugerir soluções, para as situações que os perturbam criando assim a autonomia e independência de reflexão.

Os alunos deram um novo desfecho (releituras) as histórias e confeccionaram um livro baseado nos filmes apresentados, onde não existem príncipes e sim princesas que salvaram-se lutando por seus objetivos e os conquistando.

Baseado na teoria de Coelho (2014) a professora leu o texto denominado "A princesa que salvou a si mesma" da revista digital "A mente é maravilhosa" (2017) e pediu para que os alunos e alunas criassem a sua história, incentivando-os para que escrevessem histórias pessoais para perceberem que a princesa não existe só em contos de fadas, existe na vida real e está dentro de cada uma de nós.

Também foi feita a abordagem histórica da trajetória feminina, as suas lutas e conquistas, para que os alunos pudessem se informar sobre tudo que já foi conquistado, o que está sendo conquistado e o que ainda deve ser conquistado pelas mulheres na sociedade contemporânea.

Considerando que o processo educativo pode se tornar um processo libertador fazendo com que os alunos reflitam sobre os novos papeis assumidos pela mulher e pelo homem na sociedade atual. Sendo que a busca por mais direitos femininos vem desde o final do século XIX com a luta pela educação feminina, direito de voto e abolição dos escravos. 


\section{RESULTADOS E DISCUSSÕES}

Para dar início as atividades propostas foram feitas as leituras, pela professora, dos clássicos infantis: Rapunzel, Branca de Neve e Bela Adormecida. Nestas histórias há sempre a presença necessária de um príncipe encantado para salvá-las; de uma torre, da morte e de um sono profundo.

Após vários questionamentos e análises dos contos de fadas, a professora/pesquisadora pediu para os alunos darem um novo fim para estas três histórias, que não fugissem da problematização original gerada; branca de neve morder a maçã, bela adormecida furar o dedo em uma roca e a Rapunzel estar presa em uma torre, porém, deveriam dar um novo desfecho onde elas conseguissem sair da problematização original sem ter que aparecer um príncipe para beijá-las ou encorajálas.

\subsection{A releitura da história "Rapunzel"}

O conto de fadas "Rapunzel" traz a história de uma menina que foi entregue a bruxa que conserva o seu cabelo, nunca o cortando. E quando Rapunzel completa 12 anos é trancada em uma torre, que não tinha portas nem escadas. Quando a bruxa quisesse subir ela mandava Rapunzel jogar suas tranças pela janela.

Um dia um príncipe ouviu Rapunzel cantando e se apaixonou. Ele percebeu que não havia como subir na torre e começou a frequentar as redondezas da mesma para escutar e ver Rapunzel.

Até que o príncipe vê a bruxa subindo pelas tranças de Rapunzel e quando a bruxa vai embora, ele pede que ela jogue suas tranças para ele subir e, ao subir, pediu-a em casamento. Rapunzel concordou.

Juntos armaram um plano: o príncipe viria todas as noites visitar Rapunzel e lhe traria seda, onde ela teceria gradualmente em uma escada.

Certo dia a bruxa o apanhou e na raiva cortou os cabelos da Rapunzel. Fingiu-se passar por ela quando o príncipe voltou a torre e pediu para jogar-Ihe a trança. Quando 
o príncipe se deu conta que Rapunzel não estava ali, a bruxa disse que ele nunca mais a veria e empurrou-o até os espinhos que o cegaram.

Por anos ele vagou pelas terras devastadas e por coincidência chegou ao deserto onde Rapunzel vivia. Um dia, enquanto ela cantava, ele a ouviu e quando se encontraram as lágrimas dela imediatamente restauraram a visão do príncipe e viveram felizes para sempre.

Releitura 1: Alguns anos depois Rapunzel teve coragem e falou para a bruxa que não queria viver mais lá na torre, mas a bruxa brigou com ela e disse que ela não iria sair de lá. Então no dia seguinte ela teve um plano de pegar umas madeiras com pontas grossas e sair da torre. Então Rapunzel efetuou esse plano na madrugada e conseguiu escapar e ela foi até a cidade e pediu um emprego em uma loja de roupas e depois com o salário dela alugou uma casa e morou por lá.

Releitura 2: A bruxa amarrou Rapunzel em uma árvore, depois dela ser pega tentando fugir da torre. Mas Rapunzel era esperta, carregava consigo um canivete e seu celular. Então ela cortou as cordas com o canivete e ligou para a polícia que prenderam a bruxa malvada. E Rapunzel voltou para o castelo junto com os seus pais e viveu feliz para sempre, tirando fotos para postar no Instagram".

Releitura 3: Rapunzel foi presa pela bruxa quando era pequena e então ela usou seus cabelos como corda e fugiu da bruxa. Nada de príncipes para salvá-la.

\subsection{A releitura da história "Branca de Neve"}

No conto de fadas "Branca de Neve" uma rainha má e invejosa manda matar sua enteada, Branca de Neve, por ser considerada mais bela de todo o reino. Mas o mandante de seu assassinato deixa-a partir e durante a fuga pela floresta ela encontra a casa dos sete anões que trabalham em uma mina e passam a protegê-la.

A rainha má descobre que Branca de Neve está viva e decide ela mesma matar a menina. A bruxa se disfarça de uma velha senhora e vai atrás da Branca de Neve 
oferecendo-a uma maçã envenenada, ao morder a maçã, Branca de Neve cai em um sono profundo.

Ao encontrar a Branca de Neve, os sete anões acreditam que ela está morta e a colocam em um caixão de vidro.

Em um dia o príncipe passa por ali e ao ver Branca de Neve apaixona-se, levanta a tampa de vidro do caixão e lhe dá um beijo, neste momento a Branca de Neve se acorda, se apaixona pelo príncipe e vivem felizes para sempre.

Releitura 1: Certo dia Branca de Neve passeava pela floresta, de repente uma senhora muito velhinha se aproximou, carinhosamente, perto dela oferecendo uma linda maçã. Branca de Neve nem pensou e comeu logo a maçã, nunca imaginou que se tratava da bruxa má. Os anões estavam chegando do serviço, quando de repente encontraram Branca de Neve caída no chão, os anões a levantaram e colocaram Branca de Neve em um caixão de vidro. O pai de Branca de Neve estava viajando quando tudo isso aconteceu e quando voltou de viagem ficou sabendo de tudo e foi até a casa dos setes anões e deu um beijo na testa de sua filha que acordou, imediatamente, do sono profundo, abraçou o seu pai e ficaram muito felizes novamente.

Releitura 2: Branca de Neve comeu a maçã que a bruxa tinha colocado veneno, mas de tão ruim que era, Branca de Neve foi correndo para o banheiro. A maça não fez efeito nenhum e a bruxa ficou furiosa e a Branca de Neve continuou feliz vivendo com os sete anões. Um tempo depois resolveu fazer uma casa só para ela e viveu feliz para sempre, sozinha.

Releitura 3: Branca de Neve comeu a maçã oferecida pela bruxa e caiu num sono profundo. Os sete anões a acharam e colocaram num caixão de vidro por ela ser muito bonita. Um tempo depois os sete anões escutam uma tosse e foram ver o que era, era a Branca de Neve, ela tinha apenas se engasgado com a maça e conseguiu cuspir fora, todos viveram felizes para sempre.

Releitura 4: Depois de sete horas que os anões colocaram Branca de Neve num caixão de vidro ela começou a se mexer, os anões viram isso e abriram o caixão e ela 
conseguiu respirar mais levemente. No dia seguinte ela abriu os olhos e os anões começaram a pular de alegria. Um ano depois fizeram uma festa para ela, pois era seu aniversário e deram de presente uma casa que eles mesmo construíram, ela ficou muito feliz e agradeceu.

\subsection{A releitura da história "Bela Adormecida"}

Já no conto de fadas "A Bela Adormecida" a princesa Aurora é enfeitiçada logo no seu nascimento por uma feiticeira, que disse que ela teria seu dedo picado pelo fuso de um tear para cair num sono profundo juntamente com todos do reino por 100 anos, quando completasse 15 anos, até que um príncipe encantado a desperte com um beijo.

O rei mandou destruir todos os fusos e rocas que existiam no reino, para impedir que a sua filha se picasse. Tudo em vão, ao completar 15 anos, a princesa Aurora é atraída para a floresta e lá ela encontra uma casa abandonada e decide entrar. Dentro da casa encontra um objeto pontiagudo e acidentalmente picou-se. Imediatamente a princesa cai em um sono profundo.

Um belo dia, um príncipe consegue atravessar a densa floresta que envolvia o castelo e encontra todos os seus habitantes adormecidos. Sabendo da lenda, dirige-se ao quarto da princesa e descobre a jovem mais bela que já havia visto e decide lhe beijar. Nesse momento, a princesa acorda, assim como todos do reino. Eles casaram-se e viveram felizes para sempre.

Releitura 1: Horas depois da princesa Aurora ter adormecido, um mago soube e fez uma poção para colocar ao lado dela. Então, logo depois, Aurora despertou, todos ficaram muito felizes.

Releitura 2: A Bela Adormecida quando fez 15 anos saiu para passear dentro do castelo e subiu em uma torre abandonada. Ela encontrou uma roca e tocou o dedo se machucando, ela acabou adormecendo. Mas a princesa sempre carregava seu celular junto dela e o mesmo despertou tão alto, mas tão alto que ela acordou. A princesa comprou mais rocas para fazer fio e ficou rica. 
Releitura 3: Certo dia Bela Adormecida estava curiosa para descobrir o que havia dentro de uma sala trancada. Ela conseguiu abrir e entrou bem devagarinho para que ninguém a visse entrar. Ela fechou a porta e viu algo que chamou a atenção, curiosa levantou o pano e acabou espetando seu dedo na roca. Logo caiu num sono profundo. Passaram-se muitos anos e uma fada entrou no seu quarto onde havia deixado ela por anos. A fada fez uma magia para ela despertar. A Bela despertou e perguntou para a fada o que havia acontecido. Então, a fada contou tudo nos mínimos detalhes e elas se tornaram grandes amigas.

Com base nas histórias, os alunos foram questionados sobre o que havia em comum. Eles citaram: final feliz, príncipes, princesas, beijo, bruxas, castelos, sono profundo, beleza, as princesas eram beijadas pelo príncipe enquanto elas dormiam, entre outros temas. Baseado nestas observações, a professora levantou os seguintes questionamentos: É correto beijar a princesa enquanto ela está dormindo? É necessário sempre ter um príncipe para salvar a princesa? Para a primeira pergunta os alunos responderam que "não, não é correto beijar a princesa enquanto ela dorme porque isto é abuso, é estupro e isso é crime". E para a segunda pergunta uma aluna, rapidamente, respondeu "ela pode se virar sozinha, ela é mulher!"

\section{CONTEXTO DOS FILMES CONTEMPORÂNEOS “SEM O PRÍNCIPE"}

Em continuidade a atividade de ensino, os alunos foram levados pela professora para a sala de multimídia da escola, no período de dois dias, para assistirem os seguintes filmes: Moana, Valente e Malévola.

Os filmes, diferentes das histórias clássicas que os alunos já conheciam, trazem uma nova história, também de princesas, porém onde elas lutam por seus objetivos e descobrem o que realmente é um amor verdadeiro. 


\subsection{0 filme "Moana"}

No filme "Moana", ela é uma princesa empoderada que morava em uma ilha com seus pais e desde pequena sentia o chamado dos oceanos, porém, seu pai, líder da tribo proibia qualquer viagem além do Recife e dizia a Moana que ela herdaria o seu trono e que seu lugar era ali para ajudar o seu povo.

Sua avó lhe mostra uma caverna secreta, onde se encontrava barcos à vela que seus antepassados criaram, descobrindo assim, que eles eram viajantes. Moana recebe o coração de Te Fiti, a deusa que cria a vida, que foi roubado pelo semideus, Maui, e isto espalhou desolação e destruição na ilha. Moana então resolve partir para além dos recifes, a fim de encontrar Maui e assim reestruturar a vida e a natureza que vinham se perdendo por causa da maldição. Quando eles se encontram, resolvem começar uma jornada em mar aberto, onde enfrentam terríveis criaturas marinhas, e diversas aventuras pelo mar. Após Te Fiti ser restaurada, Moana retorna à sua ilha, onde tudo volta ao normal.

\subsubsection{Análise dos alunos referente ao filme "Moana" a partir de relatos orais}

A partir de relatos orais sobre o filme "Moana" os alunos relataram o que mais chamaram sua atenção: as músicas, oceano, ensina a ser confiante e a nunca desistir dos objetivos. Constataram, que ao contrário das princesas clássicas, Moana não precisou de um príncipe para atingir seus objetivos. Nas palavras de uma aluna: "ela soube se virar sozinha".

\subsection{0 filme "Valente"}

Em "Valente", Merida não quer ser uma princesa e nem se casar, ela quer viver a vida como uma garota normal e atirar flechas. Mas sua mãe quer que ela se case com um príncipe para ajudá-la a governar o reino, porém Merida se recusa e decide ela mesma lutar por seu direito de escolher com quem e quando se casar. Nada contente com a atitude de Merida, sua mãe e a princesa discutem seriamente e Merida vai para a 
floresta. Lá ela vê umas luzes azuis e as segue até que encontra uma bruxa que faz um feitiço para que a mãe de Merida mude de ideia sobre o casamento.

\subsubsection{Análise dos alunos referente ao filme "Valente" a partir de relatos orais}

Já no filme Valente os alunos observaram que: "a garota era independente, não quer se casar com a escolha da mãe dela, não agia como as princesas dos clássicos lidos pela professora, corrigiu o seu erro, reconheceu o seu erro, lutou pelos seus direitos de escolha".

\subsection{O filme "Malévola"}

Malévola é um filme baseado na história "A Bela Adormecida", onde Malévola torna-se uma pessoa amarga e vingativa, amaldiçoa Aurora e por fim se encanta com a doçura da menina e acaba tendo um amor fraternal pela mesma. Aurora é amaldiçoada para cair num sono profundo ao completar 15 anos, sendo no filme, amaldiçoada pela Malévola. Trazendo uma versão contemporânea, Aurora, Bela Adormecida, acorda do sono profundo após o beijo de amor e verdadeiro de Malévola, quebrando os paradigmas do clássico onde o beijo que acordou a Bela Adormecida foi de um príncipe.

\subsubsection{Análise dos alunos referente ao filme "Malévola" a partir de relatos orais}

Em Malévola, durante o filme, os alunos já faziam comentários a respeito. Quando Malévola tenta voltar atrás no feitiço comentaram sobre atitudes que tomamos quando estamos com raiva. Quando Malévola beija a testa de Aurora e ela acorda ficaram empolgados e falaram que nem todo príncipe traz consigo o amor verdadeiro, que o amor verdadeiro pode vir de qualquer pessoa que realmente o sinta no seu coração.

Comparando as três histórias contadas e os três filmes assistidos, os alunos observaram que as três histórias não traz um príncipe que salva a princesa com um beijo e que no filme Moana e Valente as princesas se salvam sozinhas e lutam por aquilo que acreditam já no filme Malévola o beijo do amor verdadeiro vem de um amor maternal 
que Malévola criou pela princesa Aurora, bem diferente do que retrata o clássico conto infantil Bela Adormecida.

\title{
6 PRODUÇÃO APÓS AS ATIVIDADES
}

Após a atividade dos clássicos e da análise dos filmes e já com as atividades dos contos clássicos discutidos, o novo desafio para a turma foi à elaboração de um texto onde a chamada agora era: "Era uma vez uma princesa que salvou a si mesma", pois este foi o tema abordado pela professora em sala de aula, após a leitura das histórias e dos filmes. A professora iniciou a aula com a leitura de um texto da revista digital "A mente é maravilhosa". O texto diz o seguinte (vide Quadro 1):

\section{Quadro 1 - Era uma vez uma princesa que se salvou sozinha}

\begin{abstract}
Era uma vez uma princesa que se salvou sozinha.
Uma princesa anônima, uma princesa daquelas que caminha todos os dias nas ruas e não tem medo do sol ou do vento. Daquelas que tropeçam, mas que também se levantam. Daquelas que colecionam medos, mas também vitórias e segredos interessantes. Ninguém fala do seu valor, não é preciso porque ela o carrega escrito no coração. Ela não precisou de um príncipe corajoso porque, em vez de se aconchegar em um canto da sua cela, se atreveu a observar o dragão pela janela e encontrar seus pontos fracos. Porque ela estudou química e soube fabricar sozinha um antídoto para o veneno, um antídoto rápido e eficaz, que agiu antes que ela ficasse paralisada. Nesse conto, não houve príncipes nem beijos porque a coragem nasceu do interior da princesa, não da inspiração de outros, e a valentia se alimentou do fazer, não do esperar. Falamos de uma princesa que caminha pela vida de olhos abertos. Ela se salvou sozinha porque teve pais que entenderam que dentro dela havia um enorme potencial. Assim, não hesitaram em alimentar seus sonhos, mesmo que ela vestisse pouco rosa e vermelho, mesmo que quando pequena não sonhasse em passear com bebês de plástico ou pintar e alisar o cabelo das bonecas. Na realidade, não a pressionaram porque eles nunca sentiram que essa diferença fosse algo de que sentiriam falta.

Ela precisou de outras pessoas, naturalmente. No entanto, nunca de um príncipe que interpretava o mesmo papel que os trovadores perpetuam naqueles contos aparentemente inocentes. Ela precisou de pessoas ao seu redor, simples mortais e com inúmeros defeitos, que a apoiaram. Que deram opções de como fazer ou que inclusive, algumas vezes, a indicaram a melhor opção. Mas nunca precisou que alguém fizesse por ela. No entanto, se alguma vez alguém o fizeram, não hesitou em agradecer e até em devolver o favor. Porque a princesa, essa que se salvou sozinha, entendia que vivemos em um mundo no qual funciona, e se espera, a reciprocidade. Mas essa reciprocidade nem sempre tinha que ser paga com beijos e amor. Aliás, ela que poderia salvar com beijos e amor, porque era muito boa nisso.
\end{abstract}

Fonte: A mente é maravilhosa, revista digital, 2017. 


\subsection{Confecção dos livros}

Após a leitura do texto a professora relatou uma história verídica de uma mulher que havia se salvado sozinha, que havia passado por muitas coisas ruins e, no fim, havia conseguido alcançar seus objetivos.

Baseado no texto e na história, a professora solicitou aos alunos que fizessem uma produção de texto onde tivesse como título: "Era uma vez a princesa que se salvou sozinha".

Os alunos e alunas podiam se basear em uma história de superação, verídica ou não, em que não houvesse o famoso príncipe encantado e no final da história deveria ser feito também o desenho da princesa, que por eles foram criadas, com uso das formas geométricas sendo um conteúdo já trabalhado com os alunos, durante o ano letivo, envolvendo a área de matemática.

Foi distribuído pela professora folhas de ofícios divididas ao meio, pois desta produção tornaria um livro. Os alunos foram orientados e transcreveram suas produções para as folhas, ilustrando-as conforme a história.

O livro foi encadernado e, no mesmo, consta a bibliografia do autor (aluno), com foto e dados do mesmo.

As histórias relatadas pelos alunos, em sua maioria, foram histórias verídicas e de superação de algum momento difícil que eles e ou suas famílias passaram.

O objetivo que era fazer com que os alunos tivessem a percepção de que não é preciso um príncipe encantado para salvar a princesa, que as princesas modernas pode ser felizes e conquistar o que desejam sozinhas.

Com essa atividade, produção de texto, as alunas se empoderaram e que elas já são princesas, e podem salvaram-se, e embora sua vida não seja um conto de fadas, o final feliz existe e ela podem conquistar, e que seus medos, suas angústias e traumas podem serem superados sozinhas. 


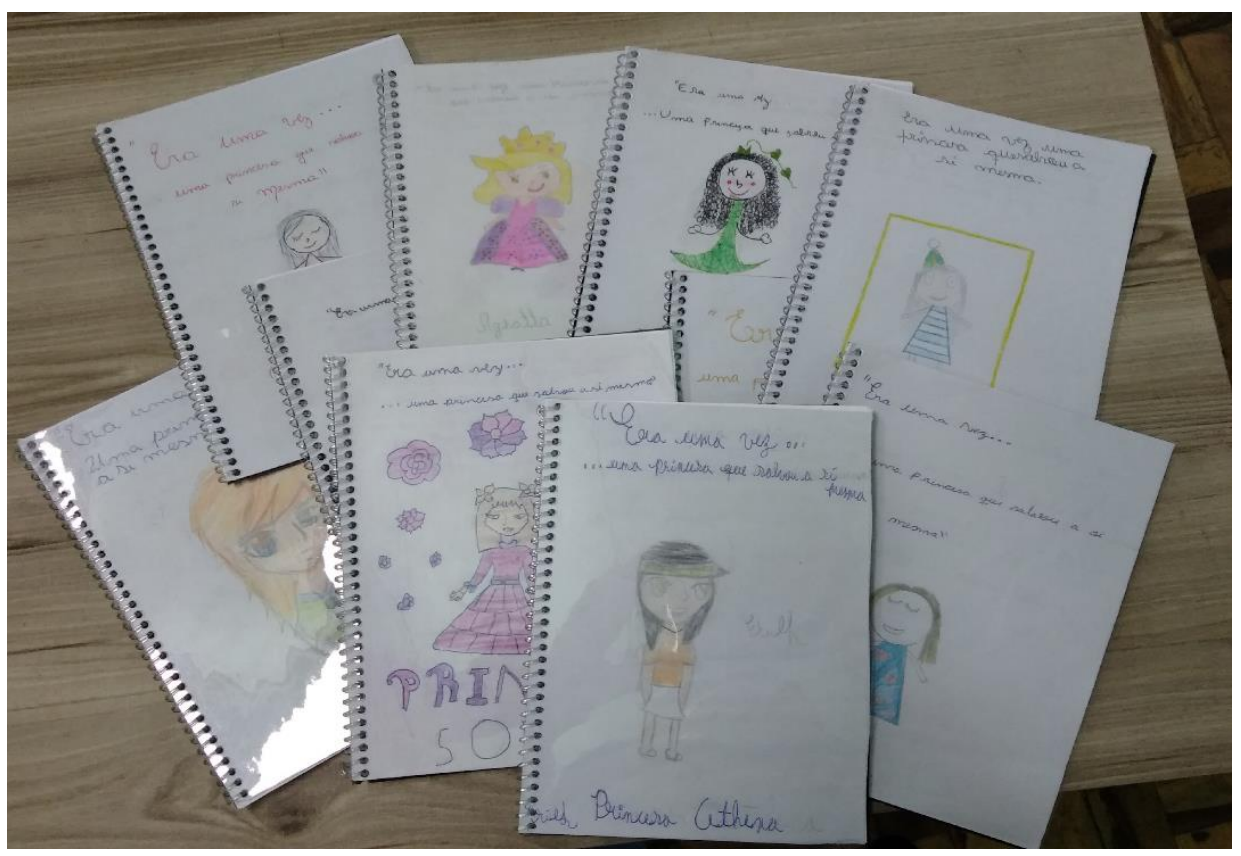

Fonte: Autores.

Com o desenho da princesa já feito, os alunos e alunas foram desafiados a darem vida à elas. As orientações da professora foi que utilizassem os materiais que achassem necessários porém para envolver a matemática deveriam usar as formas geométricas para sua confecção.

A ideia de envolver a matemática no projeto surgiu da necessidade de dar ao presente artigo uma atividade interdisciplinar que envolvessem várias as áreas do conhecimento.

O uso das formas geométricas deu-se, pois, este conteúdo já tinha trabalhado em sala de aula no segundo trimestre do ano letivo.

Juntamente com a princesa deveria vir uma ficha técnica com os seguintes dados: Nome da princesa, materiais utilizados para sua confecção e formas geométricas presentes. Abaixo o registo fotográfico do resultado da atividade. 
Figura 2 - Princesas produzidas pelos alunos utilizando formas geométricas

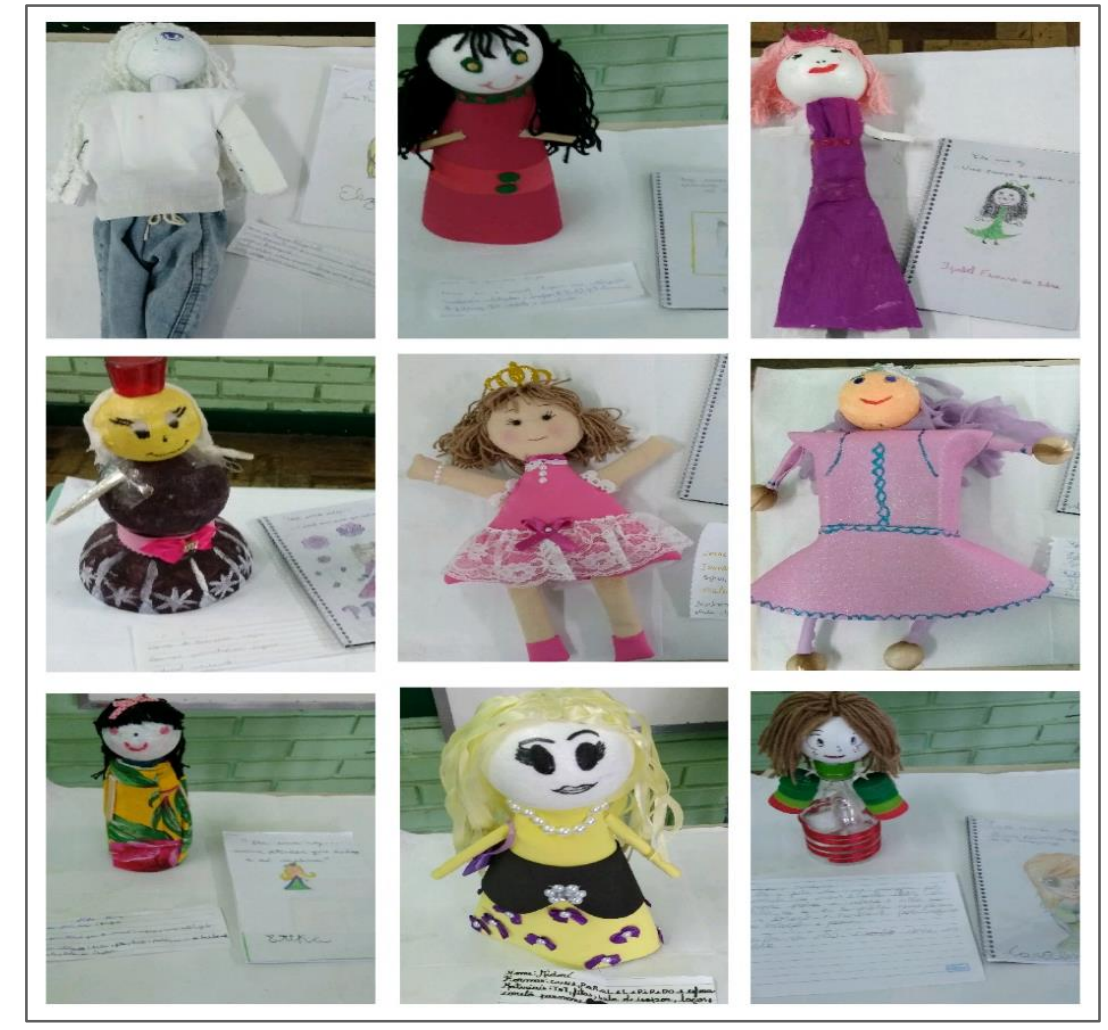

Fonte: Autores.

\section{CONCLUSÕES}

Este artigo se propôs, como objetivo geral, fazer uma reflexão sobre o papel da mulher na sociedade contemporânea, a partir da releitura dos clássicos infantis e análises de filmes contemporâneos, onde a comparação entre o papel da mulher nos dois casos é diferente, para que os alunos e alunas do ensino fundamental fizessem uma reflexão da mudança do papel do feminino na histórica contemporânea.

A intenção também foi dar subsídios teóricos e reflexivos aos educadores de todas as áreas do conhecimento, para que inspiram-se ao proporem novas práticas educativas de ensino quando forem tratar de temas relacionados ao papel da mulher. É importante, desde cedo, que as crianças quebrem os paradigmas que a sociedade apresenta ainda, de que a mulher deve ser atrelada ao contexto do sucesso ao homem na sua busca de respaldo social. 
O Brasil já possui considerável abertura normativa acerca do tema do empoderamento, tão imprescindível em uma sociedade mais atuante e imbricada na construção de uma democracia que seja reflexo do seu povo. Porém é preciso levar em conta as relações de poder entre homens e mulheres, e, desta maneira, buscar solucionar não somente condições concretas materiais das mulheres, senão também mudar as relações sociais de gênero na sociedade, construindo democracias em que a equidade de gênero seja parte da construção de uma sociedade mais justa (CRUZ, 2018, p. 113).

No contexto educativo e para que este artigo não se limitasse a teoria realizou-se práticas de leitura, oratória, escrita e arte com os alunos e alunas.

Penin e Vasconcellos (1994; 1995 apud DEMO, 2011, p.9) acreditam que "a aula que apenas repassa conhecimento, ou a escola que somente se define como socializadora do conhecimento, não sai do ponto de partida, e, na prática, atrapalha o aluno, porque o deixa como objeto de ensino e instrução, vira treinamento". Portanto, para possibilitar a aprendizagem significativa é necessário transformar o aluno em sujeito da ação de aprender.

A escola precisa garantir que o aluno tenha um papel ativo, crítico e criativo no estabelecimento da relação entre o que lê e o que sabe na avaliação do novo conhecimento, na interpretação do que está por trás do que se lê a partir do que já possui e na verificação de suas novas hipóteses.

Conclui-se o presente artigo com um resultado totalmente satisfatório, pois se percebeu a mudança de posicionamento dos alunos e especialmente das alunas, em relação ao tema abordado.

E para finalizar nada melhor do que retomar as palavras de Pitágoras, pai do conceito de Justiça, norteadora do Direito: "educai as crianças e não será preciso punir os homens".

\section{REFERÊNCIAS BIBLIOGRÁFICAS}

ANDREWS, Mark; CHAPMAN, Brenda; Animation Studios Pixar. Filme: Valente (2012) 
BETTLHEIM, Bruno. Psicanálise dos contos de fadas. São Paulo: Bertrand,13 edição, 2008.

BLOG. A mente é maravilhosa. https://amenteemaravilhosa.com.br/princesa-se-salvousozinha/. Acesso em: 28/10/2019.

BOTTON, Andressa. Educar para o empoderamento de meninas: apostas na infância para promover a igualdade de gênero. Brasília, DF, v.11 n.2, p.54-66, jan./jun. 2018.

CRUZ, Maria Helena Santana. Empoderamento das mulheres. Inc.Soc., Brasília, DF, v.11 n.2, p.101-114, jan./jun. 2018.

DEMO, Pedro. Educar pela pesquisa. 7. ed. Campinas: Autores Associados, 2011.

DISNEY, Walt. Animation Studios. Filme: Moana (2016).

FORUM. REVISTA DIGITAL https://revistaforum.com.br/digital/162/empoderamento-infantilfeminismo-e-equidade-para-criancas/ acesso em 31/10/2019.

FREIRE, Paulo. A importância do ato de ler. 49 ed. São Paulo, Cortez, 2008.

PERUZZI, Sarah Luchese; FOFONKA, Luciana. A importância da aula prática para a construção significativa do conhecimento. Porto Alegre,2013.

ROCHA, Jefferson Marçal; HAMMES, Lucio Jorge. Gestão e democracia em uma escola Pública. Revista Brasileira de Politicas e Administração da Educação. v. 34, N.2, p. 635 - 652, mai/ago, 2018.

STROMBERG, Robert. Walt Disney Pictures. Filme: Malévola (2014).

THIOLLENT, M. Metodologia da pesquisa-ação. São Paulo: Cortez, 2011

TODA MATERIA. SITE. https://www.todamateria.com.br/feminismo-no-brasil/ acesso em 31/10/2019.

TRIPP, David. Pesquisa-ação: uma introdução metodológica. Educ. Pesqui. [online]. 2005, vol.31, n.3. 